УДК: 614.849

DOI: https://doi.org/10.32689/2618-0065-2020-1(3)-176-184

Середа Дмитро Володимирович, науковий співробітник відділу досліджень i статистики пожеж науково-дослідного центру технічного регулювання, Український науково-дослідний інститут цивільного захисту, 01011, м. Київ, вул. Рибальська, 18, (096)736-27-28, sereda@undicz.dsns.gov.ua.

ORCID: 0000-0002-9645-5864

Климась Руслан Володимирович, начальник відділу досліджень і статистики пожеж науково-дослідного центру технічного регулювання, Український науково-дослідний інститут цивільного захисту, 01011, м. Київ, вул. Рибальська, 18, (067)789-93-86, r.klymas@undicz.dsns.gov.ua.

ORCID: 0000-0001-8570-6392

Маладика Лариса Володимирівна, кандидат педагогічних наук, доцент кафедри пожежно-профілактичної роботи, Черкаський інститут пожежної безпеки імені Героїв Чорнобиля Національного університету цивільного захисту України, 18034, м. Черкаси, вул. Онопрієнка, 8, (066) 92331-34, l.maladyka@gmail.com.

ORCID: 0000-0003-1644-0812

\title{
МЕТОДОЛОГІЧНІ АСПЕКТИ ОЦІНЮВАННЯ ПРОФЕСІЙНОӤ КОМПЕТЕНТНОСТІ ФАХІВЦІВ ДОСЛІДНО-ВИПРОБУВАЛЬНИХ ЛАБОРАТОРІЙ ТЕРИТОРІАЛЬНИХ ОРГАНІВ ДСНС УКРАЇНИ
}

Анотація: Стаття присвячена проблемі оцінювання професійної компетентності фахівців дослідно-випробувальних лабораторій територіальних органів Держаної служби України з надзвичайних ситуацій. Оскільки результати оцінки визначають становище фахівця на службі та перспективу його переміщення, то вони $є$ важливим мотиваційним фактором покращання трудової діяльності та ставлення до посадових обов'язків. У статті було розглянуто методологічні аспекти оцінювання персоналу та проаналізовано останні дослідження та публікації 3 даного питання. Визначено місце оцінки фахівців дослідно-випробувальних лабораторій серед інших функцій управління персоналом. Найбільш ефективним способом оцінки компетенцій являється вирішення ситуаційних задач 3 урахуванням специфіки тієї посади, що займає співробітник. Ураховуючи завдання, що покладені на дослідно-випробувальні лабораторії визначено перелік компетенції за якими слід здійснювати професійне оцінювання ії фахівців. Оцінка за визначеними компетенціями надасть керівництву 
інформацію про знання і уміння співробітника, його вміння застосовувати їх в практичній роботі, а також поведінку та особисті якості. За результатами дослідження запропоновано найбільш ефективні методи оцінки персоналу, що придатні для практичного впровадження під час проведення оцінювання компетентності фахівців дослідно-випробувальних лабораторій, що дасть визначення відповідності якісних характеристик фахівця його відповідність займаній посаді, ділових якостей, результатів праць із відповідним обладнанням, знання нормативних та керівних документів, що регламентують діяльність, можливість реалізації професійних навичок та ефективного розвитку діяльності лабораторії. Отримана інформація надасть керівництву підстави для прийняття обгрунтованих рішень, що вплинуть на ефективність діяльності лабораторії.

Ключові слова: Дослідно-випробувальні лабораторії, оцінка персоналу, система управління, критерії оцінювання, методи оцінки.

Sereda Dmytro Volodymyrovych, Researcher of the Research and Fire Statistics Branch of the Research Center of Technical Regulation, the Ukrainian Civil Protection Research Institute, 18, Rybalska str., Kyiv, 01011, Ukraine, (096)736-27-28, sereda@undicz.dsns.gov.ua

ORCID: 0000-0002-9645-5864

Klymas Ruslan Volodymyrovych, Chief of the Research and Fire Statistics Branch of the Research Center of Technical Regulation, the Ukrainian Civil Protection Research Institute, 18, Rybalska str., Kyiv, 01011, Ukraine, (067)78993-86, r.klymas@undicz.dsns.gov.ua.

ORCID: 0000-0001-8570-6392

Maladyka Larisa Volodymyrovych, PhD. (Ped.), Associate Professor of the Department of fire and prevention, Cherkasy Institute of Fire Safety named after Chornobyl Heroes of National University of Civil Defense of Ukraine, 8, Onoprienko str., Cherkasy, 18034, Ukraine, (066)923-31-34, l.maladyka@gmail.com

ORCID: 0000-0003-1644-0812

\section{METHODOLOGICAL ASPECTS OF ASSESSING THE PROFESSIONAL COMPETENCE OF SPECIALISTS IN TESTING AND RESEARCH LABORATORIES AT THE TERRITORIAL BODIES OF THE STATE EMERGENCY SERVICE OF UKRAINE}

Abstract: The present article opens the problems of assessing the professional competence of the specialists of the testing and research laboratories of the territorial bodies of the State Service of Ukraine for Emergency Situations. 
As the results of the assessment determine the position of the specialist in the service and the prospect of transfer to another position, they are an important motivational factor for improving work and attending to their job responsibilities. The article reviews the methodological aspects of staff assessment and analyzes recent research and publications on the subject. The place of evaluation of the specialists of the testing and research laboratories among other functions regulating personnel management is determined. The most effective way of assessing competencies is to solve situational problems, taking into account the specifics of the position occupied by the employee. Given the tasks assigned to the testing and research laboratories, a list of competencies for which professional evaluation of working professionals should be carried out is determined.

Assessment of specific competences will provide management with information about the employee's knowledge or ability, the latter's ability to apply them in practical work, as well as behavior and personal qualities. According to the results of the research, the most effective methods of personnel assessment, which are carried out for practical implementation during the assessment of the competence of the specialists of the testing and research laboratories, will be offered. and guidance documents governing the activity, the ability to exercise professional skills and the effective development of the action laboratory. The information thus obtained will provide the management with a basis for making informed decisions that will affect the efficiency of the laboratory.

Keywords: testing and research laboratories, personnel evaluation, management system, evaluation criteria, evaluation methods.

Постановка проблеми: На сьогодні проблема оцінки роботи персоналу поки не має конкретного загальновизнаного рішення. Існує безліч методик, стандартних і нестандартних, що допомагають оцінити окремі параметри діяльності персоналу організації. Проте додаткових досліджень потребує питання 3 визначення показників та критеріїв оцінювання професійної компетенції фахівців дослідно-випробувальних лабораторій територіальних органів ДСНС України (далі-ДВЛ), аби сам процес оцінювання мав мотиваційне й адаптаційне спрямування, що дозволяло б керівництву використовувати отримані про нього дані у процесі професійного зростання, а також підвищення ефективності діяльності підрозділу.

Аналіз останніх досліджень і публікацій: Інструментарій для оцінки персоналу з'явився ще на початку XX ст. у великих компаніях США. На теренах пострадянських країн над проблемами оцінки персоналу працював ряд вчених, зокрема Е.В. Маслов, А.М. Виноградський, Е.А. Борисова, Ф.І. Хміль, Л.Д. Кудряшова[1,2,3,4,5].

Найбільш часто питання оцінки персоналу досліджується в рамках всього комплексу управління персоналом, а самій оцінці, як важливої 
складової кадрового управління, присвячено мало робіт, в яких розглядаються лише окремі аспекти кадрової оцінки.

Автор праці [2] оцінку персоналу розглядає як функцію управління, за допомогою якої відбувається обгрунтування прийняття будь-якого управлінського рішення.

Оцінка персоналу має здійснюватися 3 метою: прийняття кадрових рішень на об'єктивній i регулярній основі; забезпечення керівників необхідними даними про кількісний та якісний склад персоналу; орієнтація працівників на покращення трудової діяльності в потрібному для організації напрямку[6].

В роботі [7] автором проведено оцінку діяльності ДВЛ за так званим комплексним оціночним балом, що розраховувався за кількісними показниками їх оперативно-службової діяльності. При проведенні оцінювання не враховувалася інформація про фахівців ДВЛ, ефективність їх роботи, потенційні можливості спеціалістів та перспективи кар'єрного зростання, причини неефективної роботи окремих спеціалістів, потреби та пріоритети в навчанні, підвищенні кваліфікації, бажання і надії працівників, а також шляхи удосконалення організації праці.

Метою статті $\epsilon$ аналіз існуючих методів професійного оцінювання персоналу, придатних для практичного впровадження, у процесі проходження ними служби в ДВЛ територіальних органів ДСНС України та визначення компетенцій оцінювання.

Виклад основного матеріалу: Оцінка персоналу - це процедура, що здійснюється 3 метою виявлення ступеня відповідності професійнокваліфікаційного рівня, ділових якостей, результатів праць із відповідним обладнанням, знання нормативних документів, що регламентують діяльність.

Оцінку компетентності персоналу використовують як елемент управління й як систему атестації кадрів. Водночас, це необхідний засіб вивчення якісного складу кадрового потенціалу ДВЛ, його сильних і слабких сторін, а також основа для вдосконалення індивідуальних трудових здібностей працівника та підвищення його кваліфікації. Оскільки результати оцінки визначають становище фахівця на службі та перспективу його переміщення, то вони $є$ важливим мотиваційним фактором покращання трудової діяльності та ставлення до посадових обов'язків.

Оцінка персоналу - доволі складна як в методичному, так i в організаційному плані робота.

Передусім потрібно зазначити, що єдиної універсальної методики, придатної для вирішення всього комплексу завдань, що пов’язані з оцінкою персоналу, просто не існує. У зв’язку з цим кожна галузь, де будь-яким чином порушується питання оцінки професійної готовності, розглядають іiі по своєму, при цьому не виходячи за межі своїх повноважень.

Оцінка персоналу може повноцінно виконувати притаманні їй функції за умов об’єктивного, надійного, достовірного, комплексного оцінювання та 
мати можливість прогнозу потенціального зростання персоналу. Крім того, методи оцінки повинні відповідати організаційній структурі підрозділу, виду і змісту діяльності, бути простими та зрозумілими для сприйняття, а також включати 5 - 6 кількісних показників і поєднувати письмову й усну форму.

У світі налічується близько двох десятків методів оцінювання персоналу, що умовно поділяються на три групи [8]. До першої групи відносяться методи описового характеру, що характеризують якості людини без кількісного їх вираження. До другої групи - методи, в основу яких покладені як описовий принцип, так і кількісні вимірювання, які визначаються на базі первинних якісних описів. До третьої - методи, в результаті використання яких можна отримати 3 достатнім ступенем об'єктивності кількісну оцінку професійних якостей осіб, тобто кількісні показники оцінювання.

Методи, включені до першої групи, як правило, носять вольовий, суб'єктивний характер. До них можна віднести:

біографічний метод - оцінка керівників і працівників згідно з даними їхньої біографії і так званих «мандатних» даних;

систему вільних усних і письмових характеристик, сутність якої полягає в тому, що керівник вищого рангу (або група керівників) описують найбільш значущі успіхи або упущення в роботі підлеглих за визначений період їх діяльності та здійснюють у зв'язку з цим певне оцінювання;

оцінку зробленого - здійснюється опис і оцінка того, що зроблено керівником за певний період діяльності;

метод групової дискусії - вільна бесіда групи керівників (або експертів) 3 керівниками та працівниками щодо їх діяльності та вибір за певними критеріями найбільш активних, самостійних, інформованих, логічно мислячих людей;

метод еталона - вибір за певними критеріями та факторами найкращих керівників, які приймаються за еталон і порівняння 3 ними всіх останніх працівників;

матричний метод - порівняння фактичних якостей керівника з набором якостей, необхідних для отримання цієї посади;

систему вільного вибору оціночних характеристик за готовими зразками та необхідного вибору оціночних характеристик за готовими зразками, коли відбувається порівняння реальних якостей працівника із завчасно підготовленими характеристиками.

До другої групи методів входять:

метод підсумкових оцінок - експертами визначається частота прояву («постійно», «часто», «іноді», «рідко», «ніколи») у керівників тих або інших якостей і присвоєння тих чи інших бальних оцінок за той чи інший рівень частоти;

система заданого групування керівників - вибір відокремленої кількості факторів оцінки, розподіл керівників за цими факторами на чотири 
групи (як правило «відмінний керівник», «добрий керівник», «задовільний керівник», «незадовільний керівник») і подальшу, так звану «пульсацію», тобто заміну добрих керівників відмінними, задовільних добрими i відмінними;

тестування - оцінка керівників згідно зі ступенем вирішення ними підготовлених професійних завдань (тестів) і встановлення на цій основі кількісних показників, які визначають рівень їх якостей;

До третьої групи методів відносяться:

метод рангового порядку - керівник (або група керівників), виходячи 3 певних критеріїв оцінки, здійснює розподіл працівників, яких він оцінює по порядку від самого кращого до самого «поганого»; в такому разі підсумкова оцінка визначається як сума отриманих працівниками порядкових номерів;

метод парних порівнянь працівників - здійснюється засобом їх послідовного попарного порівняння по всій сукупності факторів оцінки 3 точки зору загальної відносної цінності для організації;

метод заданої бальної оцінки (або метод присвоєння балів) присвоєння попередньо обумовленої кількості балів за кожне досягнення керівника з наступним визначенням його загального ділового рівня у вигляді суми набраних балів;

метод вільної бальної оцінки - присвоєння керівником (або експертом) певної суми балів за встановленою шкалою кожній якості працівника та загальній його оцінці у вигляді суми балів або середнього балу.

Крім того, всі методи оцінки поділяються на традиційні та нетрадиційні. Перші сфокусовані на окремого працівника та грунтуються на суб'єктивній оцінці керівника або колег. До них відносяться біографічний і описовий методи, методи анкет, інтерв'ю, тестування, самооцінка, методи попарного порівняння, еталона, заданого розподілення, спостереження, примусового відбору, рейтингові шкали и т.д. Традиційні методи ефективні у великих ієрархічних організаціях, що працюють в умовах досить стабільного зовнішнього середовища. Їхніми недоліками $\epsilon$ те, що оцінка дається окремому працівнику без урахування цілей організації, грунтується на оцінці керівника при повному ігноруванні думки колег по роботі, підлеглих, клієнтів і т. д.; орієнтується на минуле (досягнені результати) і не враховуються довгострокові перспективи розвитку організації і працівника. Нетрадиційні методи - це методи управління по цілям, 360 градусів, ассессмент-центр, оцінка по компетенціях, деякі інструменти психологічної діагностики й інші. Дані методи розглядають робочу групу (підрозділ, колектив) і ставлять акцент на оцінці працівника його колегами та здатності працювати в групі; оцінка окремого працівника та робочої групи проводиться 3 урахуванням результатів всієї організації; до уваги береться не тільки успішне виконання сьогоднішніх функцій, а й здібності до професійного розвитку, підвищення кваліфікації та отримання нових знань за напрямами, встановленими керівними документами, що регламентують діяльність ДВЛ. 
Український науково-дослідний інститут цивільного захисту (даліУкрНДІЦЗ) відповідно до завдань, передбачених Статутом [9], і керівними документами, що регламентують діяльність ДВЛ, здійснює координацію дослідної та випробувальної діяльності лабораторій, а також наукове i методичне керівництво їх діяльності. ДВЛ відповідно до Положення [10] та Настанови [11] створені для проведення комплексу робіт, пов'язаних 3 дослідженням пожеж і причин їх виникнення, проведенням випробувальних і дослідних робіт, а також здійснення заходів контролю за якістю виконання суб'єктами господарської діяльності робіт із вогнезахисного обробляння виробів, матеріалів, конструкцій і технічного обслуговування первинних засобів пожежогасіння.

Оскільки найбільш ефективним способом оцінки компетенцій являється вирішення ситуаційних задач з урахуванням специфіки тієї посади, що займає співробітник, пропонується здійснювати оцінку фахівців ДВЛ за наступними компетенціями (рис. 1).

Компетенція працівників ДВЛ територіальних підрозділів ДСНС

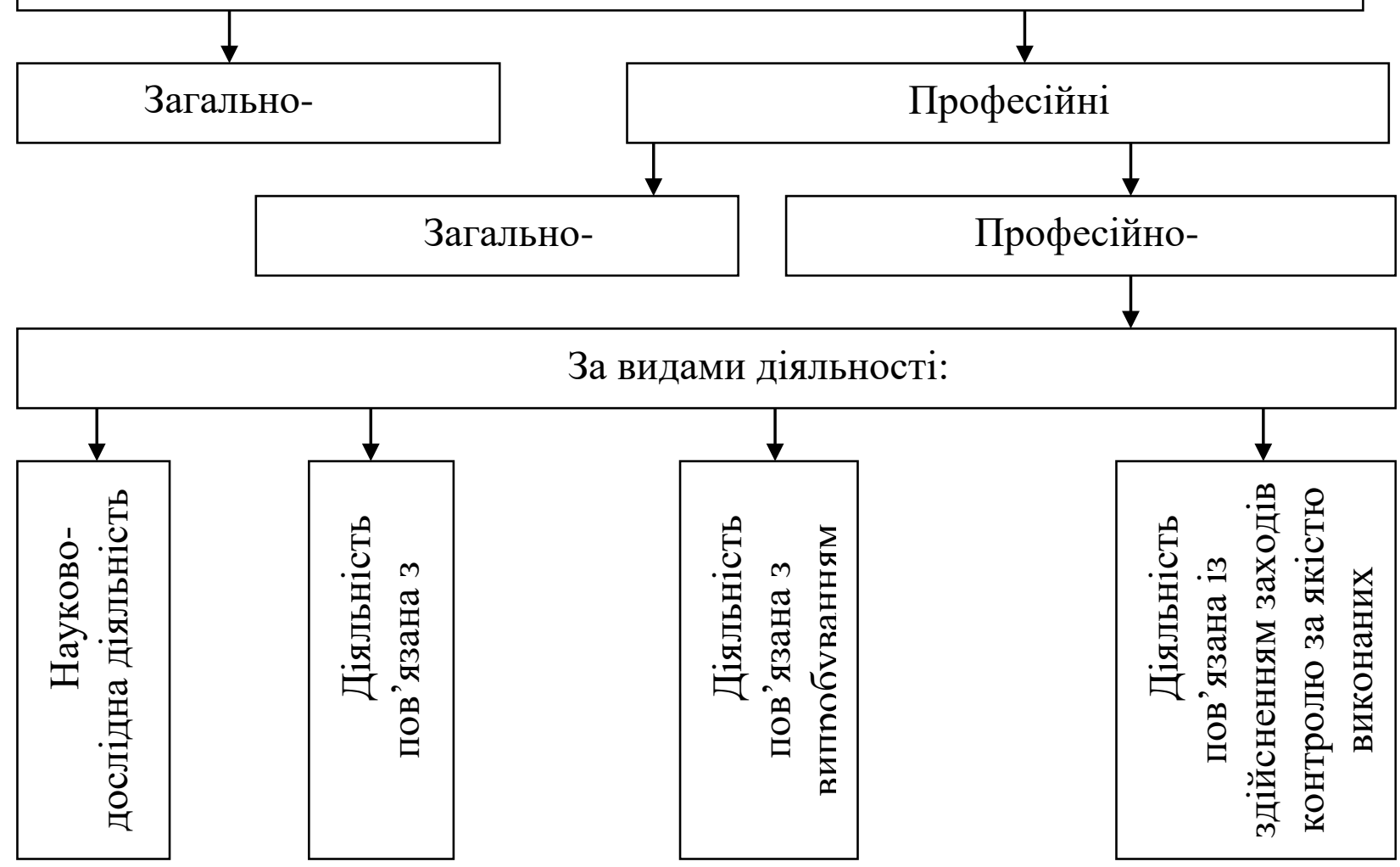

Рисунок 1. Перелік компетенцій працівників ДВЛ територіальних органів ДСНС України.

Оцінка співробітників ДВЛ за наведеним вище компетенціями надасть інформацію про знання і уміння співробітника, його вміння застосовувати їх в практичній роботі, а також поведінку та особисті якості. 
Проаналізувавши інструментарій системи оцінки, найбільш ефективними методами на думку авторів можуть бути:

1) метод 360 градусів - працівник оцінюється своїм керівником, колегами і підлеглими (серед переваг методу: визначення потреби у навчанні працівника в рамках тих компетенцій, які необхідно розвивати);

2) матричний метод - один із найбільш поширених описових методів (його суть полягає у порівнянні фактичних якостей працівників 3 набором якостей, необхідних згідно посади);

3) метод компетенції - це навички, знання, цінності виявлені в поведінці людини, що сприяють успішному досягненню результатів діяльності (серед переваг методу є мотивування працівників на освоєння високої якості виконання роботи).

Висновки: Таким чином оцінка співробітників ДВЛ цілеспрямований процес визначення відповідності якісних характеристик фахівця його відповідність займаній посаді, можливість реалізації професійних навичок та ефективного розвитку діяльності лабораторії, що дає керівництву інформацію для прийняття обгрунтованих рішень. Виходячи 3 результатів досліджень запропоновано наступні методи оцінювання професійної компетенції фахівців ДВЛ: метод 360 градусів, матричний метод та метод компетенції.

\section{Jimepamypa:}

1. Маслов Е.В. Управление персоналом предприятия: учеб. пособие / под ред. П.В. Шеметова. М.: ИНФРА-М, 2007. 325 с.

2. Виноградський М. Д. Управління персоналом : навч. посіб. / М.Д. Виноградський, А.М. Виноградська, О.М. Шканова. - 2-ге видання. - К.: Центр учбової літератури, 2003. - 502 с.

3. Борисова Е.А. Оценка и аттестация персонала / Е.А.Борисова. - СПб : Издательство: Питер, 2002. - 256 с.

4. Хміль Ф.І. Управління персоналом: навч. посібник / Ф.І. Хміль. - К.: Видавничий центр "Академія", 2006. - 488 с.

5. Кудряшова Л.Д. Системно-психологическая оценка кадров руководителей и управленческих систем. Кишинев, 1983. 249 с.

6. Пугачев В.П. Руководство персоналом: учебник / В.П. Пугачев. - М.: Аспект Пресс, 2006. - 416 c.

7. Шалупін А.В. Оцінювання діяльності дослідно-випробувальних лабораторій у 2010 році за комплексним оціночним балом / А.В. Шалупін, Н.М. Богуш // Науковий журнал. Науковий вісник УкрНДІПБ №1 (23), - К: УкрНДІПБ, 2011. - 186 с.

8. Меньшиков Л.И. Деловая оценка работников в сфере управления / Л.И. Меньшиков. - М.: Экономика, 1974. - 159 с.

9. Наказ ДСНС України Про затвердження Статуту Українського науководослідного інституту ичивільного захисту від 03 липня 2014 року № 359.

10. Наказ Держтехногенбезпеки Про затвердження примірного Положення про дослідно-випробувальну лабораторію територіального органу Держтехногенбезпеки України від 18 травня 2012 року № 133. 
11. Наказ МНС України Про затвердження Настанови з організації діяльності дослідно-випробувальної лабораторії Головного управління (управління) МНС України в області та м. Києві від 15 травня 2006 року № 289.

\section{References:}

1. Maslov, E.V. (2007). Upravlenie personalom predpriyatiya [Personnel management of the enterprise]. P.V. Shemetov (Eds.). Moscow: INFRA-M [in Russian].

2. Vynohradskyi, M. D., Vynohradska, A.M., Shkanova, O.M. (2003). Upravlinnia personalom [Personnel management]. (2nd ed.). Kyiv: Tsentr uchbovoi literatury [in Ukrainian].

3. Borisova, E.A. (2002). Otsenka i attestatsiya personala [Assessment and certification of personnel]. Saint Petesburg: Piter [in Russian].

4. Khmil, F.I. (2006). Upravlinnia personalom [Personnel management]. Kyiv: Vydavnychyi tsentr "Akademiia" [in Ukrainian].

5. Kudryashova, L.D. (1983). Sistemno-psikhologicheskaya otsenka kadrov rukovoditeley $i$ upravlencheskikh system [System-psychological assessment of manager staff and management systems]. Kishinev [in Russian].

6. Pugachev, V.P. (2006). Rukovodstvo personalom [Personnel management]. Moscow: Aspekt Press [in Russian].

7. Shalupin, A.V., Bohush, N.M. (2011). Otsiniuvannia diialnosti doslidnovyprobuvalnykh laboratorii u 2010 rotsi za kompleksnym otsinochnym balom [Evaluation of the activity of testing laboratories in 2010 according to a complex evaluation score]. Naukovyi visnyk UkrNDIPB - Scientific Bulletin: Civil Protection and Fire Security, 1(23), 163-166 [in Ukrainian].

8. Menshikov, L.I. (1974). Delovaya otsenka rabotnikov v sfere upravleniya [Business assessment of employees in the field of management]. Moscow: Ekonomika [in Russian].

9. Nakaz DSNS Ukrainy "Pro zatverdzhennia Statutu Ukrainskoho naukovo-doslidnoho instytutu tsyvilnoho zakhystu” : vid 03 lypnia 2014 roku № 359 [Order of the Ministry of Emergencies of Ukraine "On Approval of the Statute of the Ukrainian Civil Protection Research Institute” from July 03, 2014, № 359]. (n.d.). search.ligazakon.ua. Retrieved from http://search.ligazakon.ua/l_doc2.nsf/link1/FIN86877.html [in Ukrainian].

10. Nakaz Derzhtekhnohenbezpeky "Pro zatverdzhennia prymirnoho Polozhennia pro doslidno-vyprobuvalnu laboratoriiu terytorialnoho orhanu Derzhtekhnohenbezpeky Ukrainy” vid 18 travnia 2012 roku, № 133 [Order of the State Technical Committee “On Approval of the Model Regulations on the Testing and Testing Laboratory of the Territorial Body of the State Technical Committee of Ukraine” from May 18, 2012, № 133]. (n.d.). [in Ukrainian].

11. Nakaz MNS Ukrainy "Pro zatverdzhennia Nastanovy z orhanizatsii diialnosti doslidnovyprobuvalnoi laboratorii Holovnoho upravlinnia (upravlinnia) MNS Ukrainy v oblasti ta m. Kyievi” : vid 15 travnia 2006 roku № 289 [Order of the Ministry of Emergencies of Ukraine “On approval of the Instruction on the organization of activity of the testing and testing laboratory of the Main Directorate (Administration) of the Ministry of Emergencies in Ukraine and in the city of Kyiv” from May 15, 2006, № 289.]. (n.d.). search.ligazakon.ua. Retrieved from http://search.ligazakon.ua/__doc2.nsf/link1/FIN92352.html [in Ukrainian]. 